\title{
Remote sensing and modelling analysis of the extreme dust storm hitting the Middle East and eastern Mediterranean in September 2015
}

\author{
Stavros Solomos ${ }^{1}$, Albert Ansmann ${ }^{2}$, Rodanthi-Elisavet Mamouri $^{3}$, Ioannis Binietoglou ${ }^{1,5}$, Platon Patlakas ${ }^{4}$, \\ Eleni Marinou ${ }^{1,6}$, and Vassilis Amiridis ${ }^{1}$ \\ ${ }^{1}$ Institute for Astronomy, Astrophysics, Space Applications and Remote Sensing (IAASARS), National Observatory of \\ Athens, Athens, Greece \\ ${ }^{2}$ Leibniz Institute for Tropospheric Research, Leipzig, Germany \\ ${ }^{3}$ Department of Civil Engineering and Geomatics, Cyprus University of Technology, Limassol, Cyprus \\ ${ }^{4}$ School of Physics, Division of Environment and Meteorology, University of Athens, Athens, Greece \\ ${ }^{5}$ National Institute of R \& D for Optoelectronics, Magurele, Ilfov, Romania \\ ${ }^{6}$ Laboratory of Atmospheric Physics, Physics Department, Aristotle University of Thessaloniki, 54124 Thessaloniki, Greece
}

Correspondence to: Stavros Solomos (stavros@noa.gr)

Received: 11 November 2016 - Discussion started: 13 December 2016

Revised: 28 February 2017 - Accepted: 5 March 2017 - Published: 27 March 2017

\begin{abstract}
The extreme dust storm that affected the Middle East and the eastern Mediterranean in September 2015 resulted in record-breaking dust loads over Cyprus with aerosol optical depth exceeding 5.0 at $550 \mathrm{~nm}$. We analyse this event using profiles from the European Aerosol Research Lidar Network (EARLINET) and the Cloud-Aerosol Lidar and Infrared Pathfinder Satellite Observation (CALIPSO), geostationary observations from the Meteosat Second Generation (MSG) Spinning Enhanced Visible and Infrared Imager (SEVIRI), and high-resolution simulations from the Regional Atmospheric Modeling System (RAMS). The analysis of modelling and remote sensing data reveals the main mechanisms that resulted in the generation and persistence of the dust cloud over the Middle East and Cyprus. A combination of meteorological and surface processes is found, including (a) the development of a thermal low in the area of Syria that results in unstable atmospheric conditions and dust mobilization in this area, (b) the convective activity over northern Iraq that triggers the formation of westward-moving haboobs that merge with the previously elevated dust layer, and (c) the changes in land use due to war in the areas of northern Iraq and Syria that enhance dust erodibility.
\end{abstract}

\section{Introduction}

A record dust storm affected the entire Middle East and Cyprus in September 2015. Remote sensing and in situ measurements of Arabian dust from this episode during 711 September 2015 are presented by Mamouri et al. (2016) for the station of Limassol $\left(34.7^{\circ} \mathrm{N}, 33^{\circ} \mathrm{E}\right)$. As reported in this article, the extreme amounts of dust over the Middle East and the eastern Mediterranean originate from the desert and arid areas of Syria and northern Iraq. Triggered by this work, we analyse the main processes that resulted in the mobilization of dust due to a combination of cyclonic flow and haboob formation.

Haboobs are local and mesoscale atmospheric density currents that mobilize huge amounts of dust and create a propagating dust wall extending up to $2-3 \mathrm{~km}$ in the troposphere (Knippertz et al., 2009; Solomos et al., 2012). These systems are well known by local populations in desert and arid areas worldwide, due to their devastating impact on visibility and human health (e.g. Schepanski et al., 2009; Emmel et al., 2010; Dempsey, 2014; Pantillon et al., 2016). Haboobs are formed by the evaporation (and melting) of hydrometeors as they fall through warm, unsaturated air below the cloud base of convective clouds. The energy required for these phase changes (latent heat) generates cooled down- 
drafts. When the downdrafts hit the surface, they spread out due to their enhanced density compared with the ambient air. These convective outflow boundaries are turbulent and gusty, and when they travel over bare soil and desert areas, sediment can be lifted, creating a propagating dust wall. The scale of the processes that participate in the generation of such atmospheric density currents ranges from synoptic down to mesoscale and local. As a result, haboobs and their effects on weather and air quality cannot be resolved by the coarse global model resolutions (Marsham et al., 2013). Moreover, haboobs are usually generated over remote arid areas, where no in situ networks are present and on-site dust-storm measurements can only be obtained during field campaign experiments (e.g. SAharan Mineral dUst experiMent, SAMUM, 1 and 2; Ansmann et al., 2011; FENNEC, Ryder et al., 2015). Following these limitations, most of the efforts for the studying and forecasting of such intense dust episodes rely on passive and active remote sensing (e.g. Moderate Resolution Imaging Spectroradiometer, MODIS; European Aerosol Research Lidar Network, EARLINET; and Cloud-Aerosol Lidar and Infrared Pathfinder Satellite Observation, CALIPSO) and on high-resolution modelling simulations. Assimilation of satellite-derived aerosol optical thickness (AOT) has been shown to improve the dust forecasts in global models especially for the long-range transport (Benedetti et al., 2009); however, this approach cannot be easily adopted for the description of haboobs. The reason is that the convective events and the associated wind gusts are not properly resolved at coarse model resolutions. As a result, assimilating the satellite AOT over an inaccurate meteorological field does not improve the dust forecast.

A variety of studies on haboobs have been performed worldwide. For example, Knippertz et al. (2009), Reinfried et al. (2009), Solomos et al. (2012), and Roberts and Knippertz (2014) analysed the physical processes that lead to severe haboob formation in the Sahara. Bou Karam et al. (2008) showed the contribution of the east Atlantic monsoon flow and the associated mesoscale convective systems in dust elevation along the Sahel. Vukovic et al. (2014) described the severe convective dust storm that hit Phoenix, Arizona, in July 2011. Asian haboobs from the Taklimakan and Gobi deserts are described and simulated in Takemi $(1999,2005)$. All these studies agree on the complexity of the various physical processes at multiple atmospheric scales that govern the generation and lifetime of these systems. Apart from their devastating effects at local and near-surface scales, such events may also contribute to the free-troposphere dust burden in several ways. First, the entrainment of dust particles in the free troposphere takes place at the turbulent region of the density current head (Takemi, 2005; Solomos et al., 2012). Second, they trigger secondary convective cells along their pathways that may evolve to synoptic-scale dust events. And third, dust residuals remain aloft after the cold pool declines.
The current article is the second part (part 2) in a series of articles on the September 2015 extraordinary dust storm in the Middle East and eastern Mediterranean. In part 1, Mamouri et al. (2016) presented a detailed analysis of remote sensing and in situ monitoring of the event over Cyprus. The formation of similar events is not fully understood, and we use this unique episode to elucidate the mechanism of dust production in this understudied region. Therefore, EARLINET measurements over Cyprus, along with CALIPSO and MSG observations, are used to fine-tune the Regional Atmospheric Modeling System (RAMS) simulations and explain the physical processes that resulted in this haboobdriven dust storm. We focus our analysis on the first 2 days of the event (6 and 7 September 2015), when the extraordinary dust storm was generated. To the best of our knowledge, this is the first detailed modelling and remote sensing study to describe a Middle East haboob. The modelling and measurement techniques for the analysis are presented in Sect. 2. Section 3 includes the model results, the remote sensing, and the investigation of the atmospheric processes that led to the formation of the dust episode. Conclusive remarks and discussion are presented in Sect. 4.

\section{Instruments and models}

\subsection{Remote sensing}

\subsubsection{EARLINET}

The lidar station at Limassol $\left(34.7^{\circ} \mathrm{N}, 33^{\circ} \mathrm{E} ; 23 \mathrm{~m}\right.$ a.s.l. metres above sea level) is part of the European Aerosol Research Lidar Network (Pappalardo et al., 2014). The EARLINET is widely used for aerosol characterization and, particularly, for dust characterization studies (Mona et al., 2012). Details on the lidar station equipment and the retrieval algorithms are given in Mamouri et al. (2016). Dust mass concentration profiles are obtained from the dust optical properties following the methodology proposed by Ansmann et al. (2012).

\subsubsection{CALIPSO}

The Cloud-Aerosol Lidar with Orthogonal Polarization (CALIOP) is the principal instrument on board the CALIPSO satellite. CALIOP is a standard dual-wavelength (532 and $1064 \mathrm{~nm}$ ) backscatter lidar, operating a polarization channel at $532 \mathrm{~nm}$ (Winker et al., 2009), and it has been acquiring high-resolution profiles of the attenuated backscatter signal at 532 and $1064 \mathrm{~nm}$, along with polarized backscatter signal in the visible channel, since 2006. After calibration and range correction of the lidar backscatter signals (Level 1 CALIPSO product), cloud and aerosol layers are identified and aerosol backscatter and extinction coefficient profiles at 532 and $1064 \mathrm{~nm}$ are retrieved as part of the Level 2 CALIPSO product. The CALIPSO algorithms 
are described in detail by Winker et al. (2009). In this study, we utilize L2 version 3 aerosol and cloud profile products at a horizontal resolution of $5 \mathrm{~km}$ and vertical resolution of $60 \mathrm{~m}$ (in altitudes up to $8 \mathrm{~km}$ a.s.l.). In extreme haboob events, where the optical signal is very high, it is possible for the algorithm to wrongly attribute a dust layer as a cloud. In order to address this issue and fully understand the observed scene, we use collocated information derived from Meteosat Second Generation (MSG) Spinning Enhanced Visible and Infrared Imager SEVIRI (see Sect. 2.1.3). In the two CALIPSO cases used here, MSG-SEVIRI RGB images confirmed that CALIPSO overpasses were cloud free; hence, we classify both aerosol and cloud categorized CALIPSO observations as aerosol.

Moreover, both of the cases have significantly high particle depolarization ratio values, which is a signature of pure dust scenes. In order convert the dust extinction coefficient from CALIPSO into dust mass concentration, we follow the methodology proposed by Ansmann et al. (2012), using the conversion parameter of desert dust that is proposed in Mamouri and Ansmann (2014). For this case study, we use a lidar ratio of $40 \mathrm{sr}$ that is typical for Middle East dust (Mamouri et al., 2013). The overall uncertainty in the estimated dust mass concentrations is $20-30 \%$.

\subsubsection{MSG-SEVIRI}

The Meteosat dust RGB composite is produced from a combination of three infrared channels of SEVIRI: IR12.0IR10.8 (red), IR10.8-IR8.7 (green), and IR10.8 (blue). The channel combination and visualization parameters (Table 1) were chosen to maximize the visual contrast between the hot desert surface and lofted dust particles (Lensky and Rosenfeld, 2008). During daytime, the hot desert sand, made up of large quartz particles, appears white and blue due to the large difference in emissivity of IR10.8 and IR8.7 channels (green), high temperature (blue), and quite a large difference in IR12.0 and IR10.8 channels (red). In contrast, lofted dust plumes with fine quartz particles have similar values of emissivity at IR10.8 and IR8.7, and this makes dust appear pink or magenta. Deep cumulonimbus clouds are depicted with red colours, while thick water clouds appear yellow. The RGB dust product is a very useful tool to qualitatively monitor dust transport events, taking advantage of the high temporal resolution of SEVIRI observations. The dust RGB product is provided in hourly intervals by EUMETSAT (European Organization for the Exploitation of Meteorological Satellites) and is used in this work to monitor the evolution of the dust transport event.

In some cases, however, the usefulness of the product can be limited; this should be considered in the following discussion. First, the visual contrast between dust and the underlying surface is diminished when the temperature difference between the two is low, e.g. during nighttime. Second, high levels of columnar water vapour or the presence of the tem-
Table 1. Range and gamma $(\Gamma)$ correction for the red, green, and blue channels that construct the dust RGB product.

\begin{tabular}{llrrr}
\hline Colour & SEVIRI channels & Min (K) & Max (K) & $\Gamma$ \\
\hline Red & IR12.0-IR10.8 & -4 & 2 & 1 \\
Green & IR10.8-IR8.7 & 0 & 15 & 2.5 \\
Blue & IR10.8 & 261 & 289 & 1 \\
\hline
\end{tabular}

perature inversion can mask the presence of dust in the atmosphere (Brindley et al., 2012). Finally, the contrast between dust and the ground can be further diminished over some type of surfaces, e.g. over rocky terrain, due to its high emissivity at the $8.7 \mu \mathrm{m}$ channel (Banks and Brindley, 2013).

\subsection{Modelling}

\subsubsection{RAMS-ICLAMS model}

For the simulations used in this study, we adopt the online coupled atmospheric and air quality Regional Atmospheric Modeling System and Integrated Community Limited Area Modeling System, RAMS-ICLAMS (Pielke et al., 1992; Meyers et al., 1997; Cotton et al., 2003; Solomos et al., 2011). The Integrated Community Limited Area Modelling System is an enhanced version of RAMS6.0, and it was developed by the Atmospheric Modelling and Weather Forecasting Group at the University of Athens, Greece. The model is set up in a two-way nesting configuration. The external domain grid space is set at $12 \mathrm{~km} \times 12 \mathrm{~km}$, and the grid space of the inner domain is set at $4 \mathrm{~km} \times 4 \mathrm{~km}$. A higher-resolution (cloud-resolving) grid at $2 \mathrm{~km} \times 2 \mathrm{~km}$ is nested over the haboob generation area at the Syria-IraqIran-Turkey borders. The locations of the model domains are shown in Fig. 1. The vertical structure of the model consists of $50 \sigma-z$ terrain-following levels. The first model level is at $50 \mathrm{~m}$ above ground, and the levels stretch from the surface up to $18 \mathrm{~km}$. The dust emission scheme follows the saltation and bombardment approach (Marticorena and Bergametti, 1995; Spyrou et al., 2010). Wet and dry deposition of dust is formulated following Seinfeld and Pandis (1998). Mineral dust is represented with a transport mode of eight radii bins, namely $0.15,0.25,0.45,0.78,1.3,2.2,3.8$, and $7.1 \mu \mathrm{m}$. Sea salt aerosol is also parameterized following Monahan et al. (1986), Zhang et al. (2005), Leeuw et al. (2000), Gong et al. (2002), and Gong (2003), and it is represented with an accumulated and a coarse mode at 0.18 and $1.425 \mu \mathrm{m}$ in radius, respectively. Dust and sea salt particles interact with the radiative transfer code of the model (rapid radiative transfer model, RRTM; Mlawer et al., 1997; Iacono et al., 2000) for the computation of heating-rate fluxes. The formation of cloud condensation nuclei and ice nuclei from dust and sea salt particles is also included in the model based on the schemes of Fountoukis and Nenes (2005) and Barahona and Nenes (2009). Initial and boundary conditions are from the 


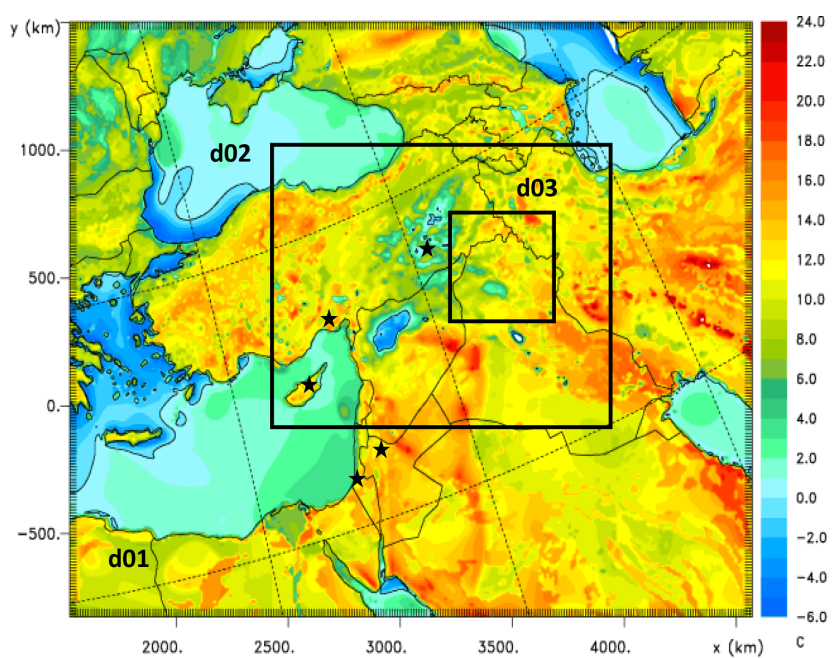

Figure 1. Modelling domain structure and difference $\left({ }^{\circ} \mathrm{C}\right)$ between model soil temperature and model temperature at $2 \mathrm{~m}, 10: 00 \mathrm{UTC}$, on 6 September 2015. The black rectangles indicate the location of the nested model domains (d01: $12 \times 12 \mathrm{~km}$; d02: $4 \times 4 \mathrm{~km}$; d03: $2 \times 2 \mathrm{~km}$ ), and black stars indicate the locations of radiosondes.

National Centers for Environmental Prediction, NCEP, final analysis dataset (FNL; at $1^{\circ} \times 1^{\circ}$ resolution), and the sea surface temperature is the NCEP operational sea surface temperature $(\mathrm{SST})$ at $0.5^{\circ} \times 0.5^{\circ}$. The convective parameterization scheme of Kain and Fritsch (1993) is activated for the two coarser grids. Assimilation of radiosonde data from the airports of Adana $\left(36.98^{\circ} \mathrm{N}, 35.35^{\circ} \mathrm{E}\right.$; 00:00 and 12:00 UTC), Bet Dagan $\left(32.00^{\circ} \mathrm{N}, 34.81^{\circ} \mathrm{E}\right.$; 00:00 and 12:00 UTC), Diyarbakir $\left(37.54^{\circ} \mathrm{N}, 40.12^{\circ} \mathrm{E} ; 00: 00\right.$ and 12:00 UTC), Mafraq $\left(32.36^{\circ} \mathrm{N}, 36.25^{\circ} \mathrm{E} ; 21: 00 \mathrm{UTC}\right)$, and Nicosia $\left(35.10^{\circ} \mathrm{N}\right.$, $33.30^{\circ} \mathrm{E}$; 00:00 UTC) is also activated to fine-tune the simulations. A series of sensitivity runs with various model configurations (different physical schemes, assimilation parameters, and domain structures) is performed until we conclude to the optimum setup for the specific simulation.

\subsubsection{Land-use changes and activation of dust sources}

An accurate representation of dust sources in the region is crucial for understanding this complex dust event, but this is hampered by seasonal and interannual variability of dust sources together with recent land cover changes in the region. The original land-use database of the model is the USGS Global Land Cover Characteristics Data Base Version 2, which is obtained from $1 \mathrm{~km}$ AVHRR (Advanced Very High Resolution Radiometer) data spanning April 1992 through March 1993. First, this annual-mean dataset cannot accurately describe the land use and dust sources at the end of the dry season in the Middle East. Second, the complex interactions of drier climate (Notaro et al., 2015; Cook et al., 2016), transboundary water managements (Voss et al., 2013), and prolonged conflict (Jaafar and Woertz, 2016) have led to further changes of land-use types that are no longer reflected at the model, and this could have a large impact on dust production. The comparison of Landsat 8 natural colour and normalized difference vegetation index (NDVI) imagery between August 2013 and 2015 (Fig. 2) reveals large areas of uncultivated fields in regions of contested borders and exposed river and lakebed sediments, especially around the Euphrates River, all of which are known to be very efficient dust sources (Prospero et al., 2002; Ginoux et al., 2012). The impact of the ongoing conflict on land use and vegetation can be further highlighted in Fig. 3, showing the time series of MODIS NDVI in the region around Hawija, Kirkuk province, Iraq (region B of Fig. 2). Agriculture in Hawija is based on a combination of rain-fed and irrigated fields, in accordance with a rainy and a dry season from November to May and from June to October, respectively. The NDVI time series clearly captures this behaviour, with a major annual NDVI pick during wet months and a smaller cycle during each summer, probably reflecting the growth of summer crops with the help of irrigation. This summer cycle is completely absent in 2015. Indeed, a recent survey of the Food and Agriculture Organization (FAO) of the United Nations reveals that large parts of the irrigation system in Kirkuk and the surrounding regions have been destroyed by military operations and a large number of pumps and generators required for irrigation have been stolen (Singh et al., 2016). This, together with the destruction of other agricultural equipment and infrastructures, has severely disrupted the summer agriculture activities of 2015, exactly before the dust storm studied here, leaving the fields to act as very efficient dust sources.

In order to get the most accurate representation of dust sources for the specific event, we use $1 \mathrm{~km}$ monthly NDVI from MODIS (Didan, 2015) to characterize land-use type in the region of interest. Specifically, we consider regions with NDVI values from 0 to 0.1 to correspond to bare soil and, consequently, efficient dust sources (DeFries and Townshend, 1994). The updated land cover dataset is used for all results shown in this study. Results from simulations using the older database are only shown in Fig. 11 for comparison.

\section{Results}

\subsection{Meteorological conditions}

The main driving force for the generation of this extreme dust episode is the combination of two distinct meteorological features in the greater area: (i) establishment of a thermal low over the bare-soil areas of Syria and (ii) convective outflow boundaries at the mountains of Iraq and Syria. These processes are analysed in the following sections using modelling results and remote sensing. 
Land type changes in 2015

(a)

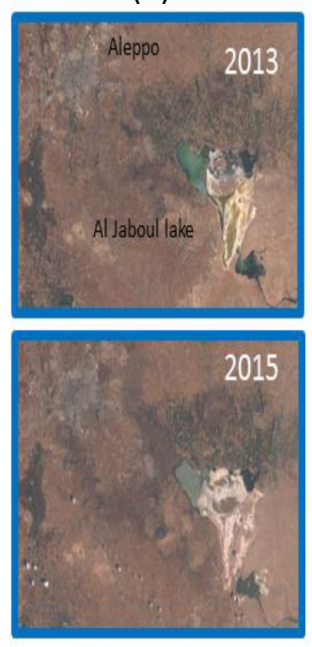

(d)

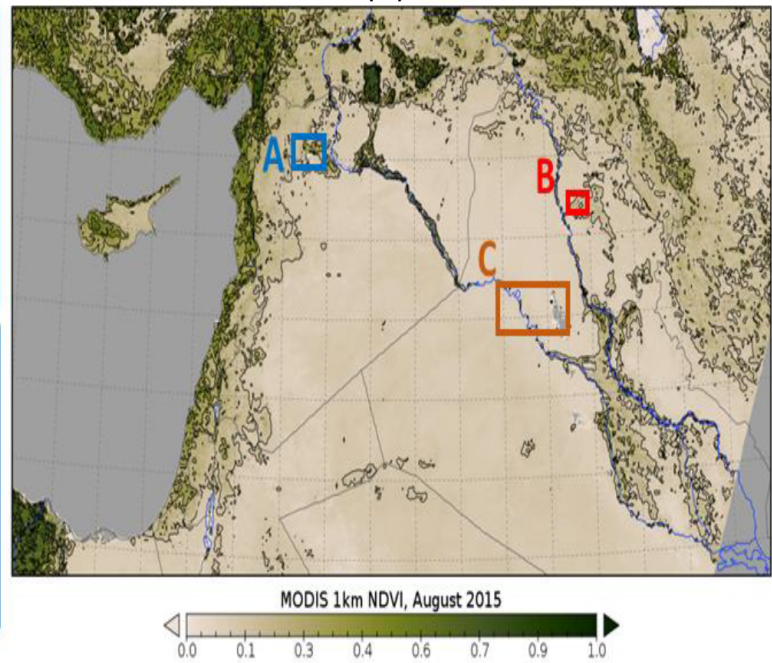

(b)

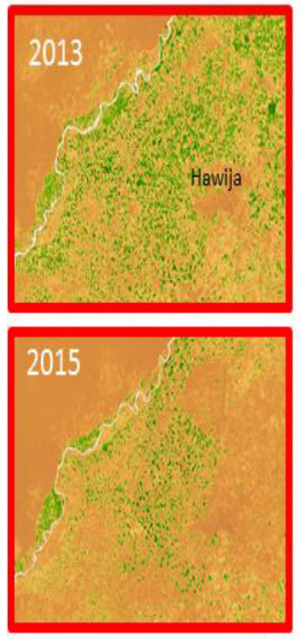

(c)

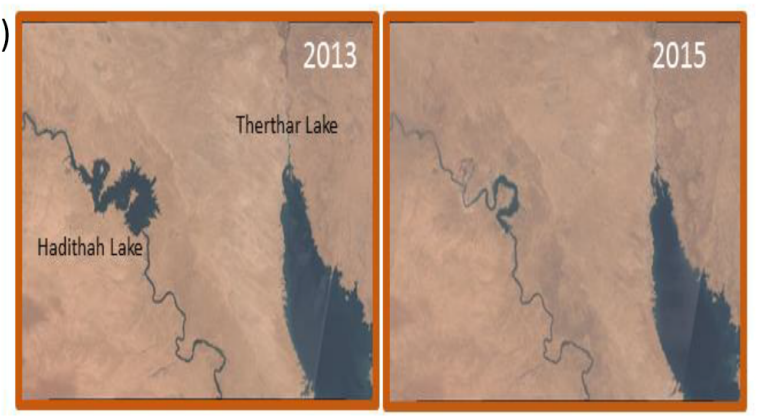

Figure 2. MODIS NDVI observations for August 2015 were used to identify regions of bare soil that can be sources of dust aerosols. The contour lines correspond to the major ticks of the colour scale. Large regions of western Syria and Iraq have NDVI values from 0 to 0.1 . The three subpanels show examples of land type changes between summer 2013 and summer 2015. (a) Landsat 8 natural colour images of the Aleppo region, Syria, show changes of cultivation patterns and drying of the nearby Al Jaboul lake (e.g. the bright areas of the Al Jaboul Lake, dry parts of the lake, increased from 2013 to 2015); (b) Landsat 8 NDVI images in the region of Hawija, Kirkuk Province, Iraq, reveal that large areas remained uncultivated in 2015 (e.g. the 2013 map shows many more green spots, agriculturally used areas, than the 2015 map); (c) Landsat 8 natural colour images showing the diminishing area of Haditha Lake on the Euphrates River and the drying up of the Therthar canal and lake.

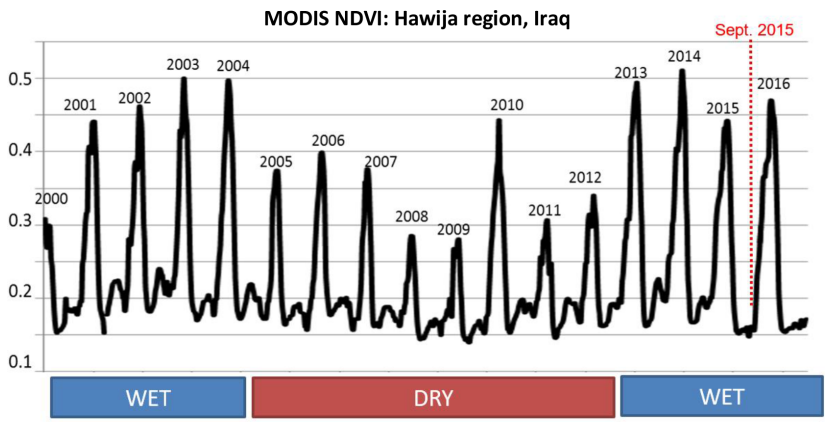

Figure 3. Time series of the 16-day NDVI for the agricultural region around Hawija, Kirkuk province, Iraq. The vertical dashed lined marks the time of the studied dust storm. Note the absence of NDVI variation in the summer of 2015 , prior to the dust storm.

\subsubsection{Development of a low-pressure system over Syria on 6 September 2015}

As seen at the outer model grid in Fig. $4 \mathrm{a}$, the passage of a trough is evident over Turkey on 6 September 2015 , 00:00 UTC. The low-pressure centre at $500 \mathrm{mbar}$ is found at $5840 \mathrm{~m}$ over the east bank of the Black Sea. During the same day, radiative warming of the bare-soil surface results in very hot soil temperatures exceeding $50^{\circ} \mathrm{C}$ in Syria and Iraq. Advection of warm air from the Red Sea is also evident at the lowest troposphere in the 1000-700 mbar thickness in Fig. 4b. This combination of cold air aloft with low-level warming leads to the formation of a thermal low-pressure system over Syria that is evident in the 925 mbar geopotential height in Fig. 4c. Another parameter that plays an important role for the process of dust source activation is the dif- 

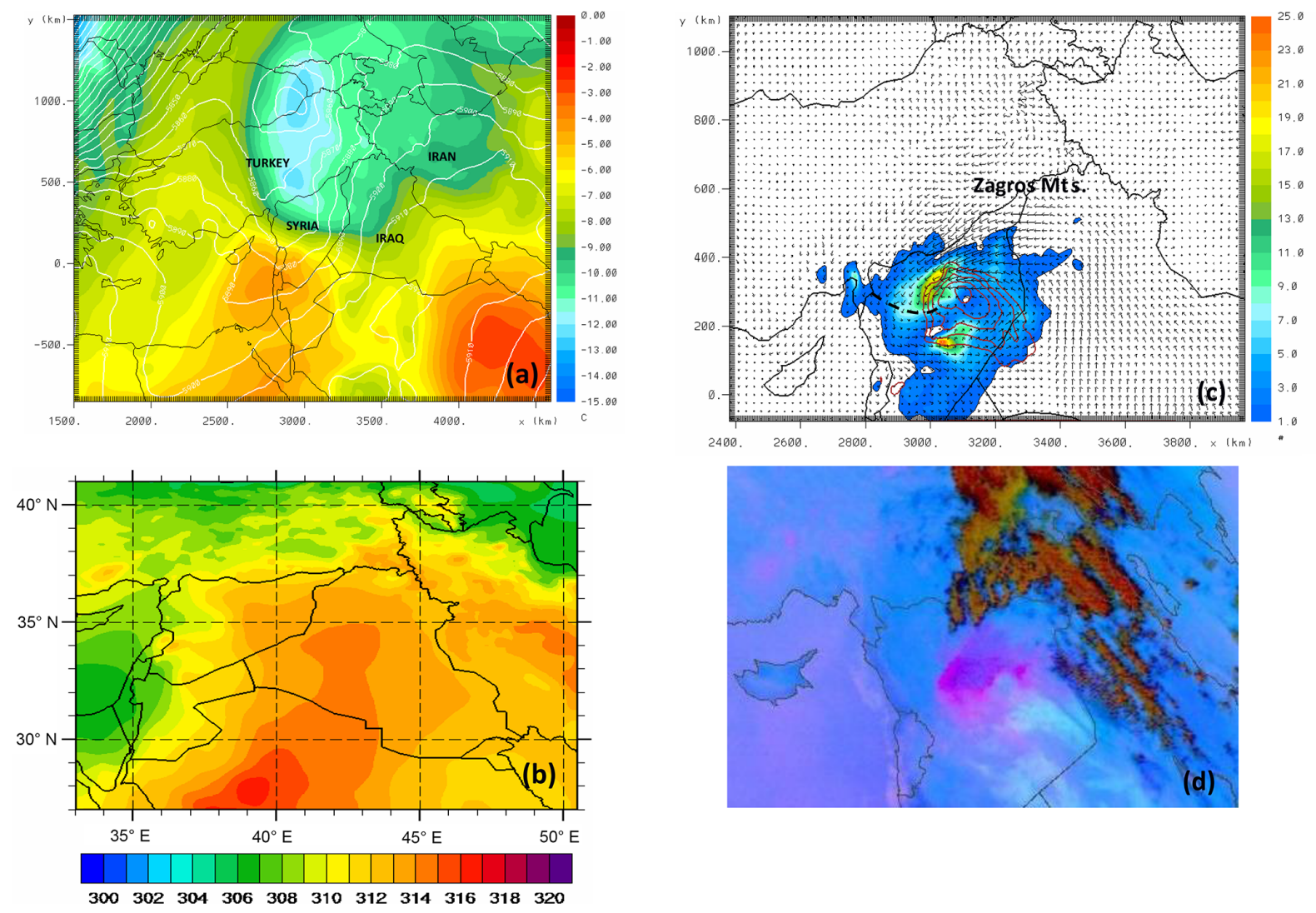

Figure 4. (a) Model geopotential height contours (every $10 \mathrm{~m}$ ) and temperature (colour scale in ${ }^{\circ} \mathrm{C}$ ) at 500 mbar on 6 September 2015 , 00:00 UTC. (b) Model 1000-700 mbar thickness (dam) on 6 September 2015, 00:00 UTC. (c) Model AOT (colour scale), geopotential height at $925 \mathrm{mbar}$ (red contours from 740 to $757.5 \mathrm{~m}$ every $2.5 \mathrm{~m}$ ), and wind vectors at $925 \mathrm{mbar}$. The dashed line denotes the outflow boundaries from the Zagros Mountains. (d) MSG-SEVIRI dust RGB at 08:00 UTC, 6 September 2015.

ference between surface temperature ( $\left.T_{\text {Surf }}\right)$ and air temperature at $2 \mathrm{~m}\left(T_{2} \mathrm{~m}\right)$. Findings from earlier field experiments (i.e. SAMUM) show that such a difference of $17-20^{\circ} \mathrm{C}$ facilitates the uplift of convective dust plumes (Ansmann et al., 2009). As seen in Fig. 1, the modelled $T_{\text {Surf }}-T_{2 \mathrm{~m}}$ difference at 10:00 UTC exceeds $17^{\circ} \mathrm{C}$ over extended bare-soil areas in Syria. This temperature gradient further explains the effectiveness of dust production at these areas. The pressure system and the associated cyclonic flow persist during the entire day of 6 September 2015 and result in the mobilization of dust in the area. Dust uptake is mostly evident at the outer parts of the cyclone, where surface wind speed exceeds $7 \mathrm{~m} \mathrm{~s}^{-1}$ almost during the entire day and $T_{\text {Surf }}-T_{2 \mathrm{~m}}$ obtains maximum values. The elevated particles are quickly distributed inside the system and a distinct cylindrical dust cloud is soon formed. Recirculation of the elevated dust particles inside the closed cyclonic flow results in extreme AOT values exceeding 15 at specific areas as seen in Fig. 4c. The formation of this dense dust plume is also evident in the MSG-SEVIRI satellite dust RGB image in Fig. 4d. The pink and purple colours in this image indicate dust, while brown and red colours indicate clouds. The convective out- flows from the Zagros Mountains in Turkey that are evident by the black dashed line and wind vectors at $925 \mathrm{mbar}$ in Fig. $4 \mathrm{c}$ enhance the mobilization of dust at the northern parts of the heat low. Transport of dust from Lebanon towards Cyprus is evident in the satellite and modelling images on 7 September 2015, 00:00 UTC (Fig. 5). This cut-off plume (plume_1) travels in the lower troposphere above the marine boundary layer, and it was observed at $1.5 \mathrm{~km}$ above Limassol on 7 September, 19:00 UTC, as reported by Mamouri et al. (2016). The faster propagating haboob plume (plume_2) was detected at 2.0-3.5 km over Cyprus at 19:00 UTC. The extreme AOT values $(>10)$ that are seen in Fig. 5a over Syria result from the overlapping of cyclone-driven and haboobdriven dust over this area. In the model, approach of the haboob front in Syria is also accompanied by cloud formation, as seen by the $70 \%$ cloud-cover contours in Fig. 5a; however, these clouds are not evident in the satellite image (Fig. 5b). The more elevated (cyclone-driven) dust in Fig. 5b is shown in pink (plume_1 over the sea and plume_3 over northern Syria and southern Turkey), and the near-surface dust (haboob) is shown with a darker purple colour (plume_2). 

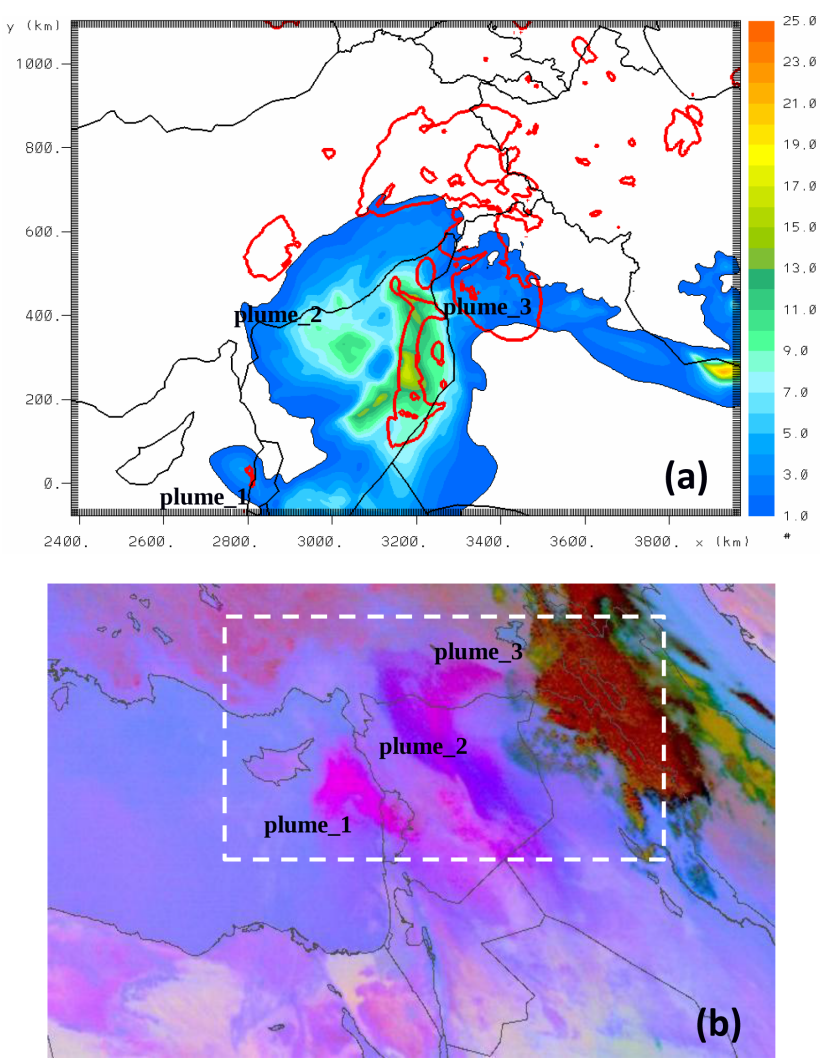

Figure 5. (a) Model AOT at $550 \mathrm{~nm}$ (colour scale) and cloud cover $>70 \%$ (red contour). (b) MSG-SEVIRI dust RGB component on 7 September 2015, 00:00 UTC. The white rectangle approximately indicates the location of the model domain shown in (a).

\subsubsection{Convection and haboob generation on 6 and 7 September 2015}

At 13:00 UTC on 6 September, a northward low-level flow is evident over N Iraq and N Syria (Fig. 6a). This relatively unstable air mass is characterized by an increased equivalent potential temperature $\left(\theta_{\mathrm{e}}\right)$ reaching up to $508 \mathrm{~K}$. This flow is associated with a westerly shift of the Somalian lowlevel jet (SLLJ). The SLLJ is part of the west India Monsoon circulation and is shown in Fig. 6b. It is characterized by strong SW winds blowing from the Somali highlands towards western India. This low-level flow steers towards the west along the coastal mountains of Yemen and Oman and results in SE winds transferring moisture from the Arabian Sea towards the interior of the Arabian Peninsula. Low-level advection of warm air masses from the Red Sea and Saudi Arabia towards the storm area is also evident in Fig. $6 \mathrm{c}$ in the 1000-700 mbar modelled thickness at 15:00 UTC. The mechanical elevation of this relatively unstable air as it approaches Mt Sinjar in N Iraq triggers convection in this area. A number of atmospheric parameters that determine the formation of the cold pool are shown in Fig. 7a-d. As seen in Fig. 7a, the iso-temperature line of
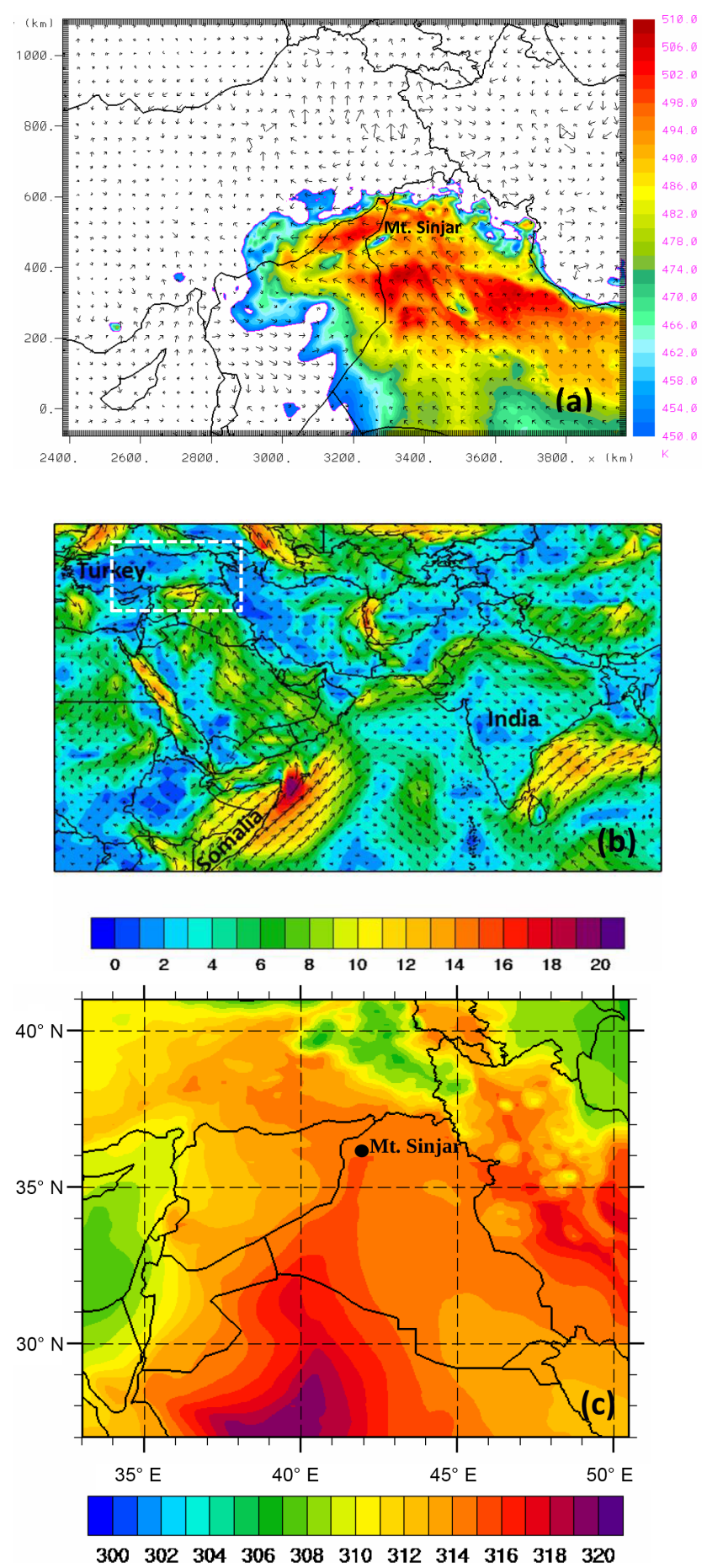

Figure 6. (a) Model equivalent potential temperature (K) and wind vectors at $50 \mathrm{~m}$ above ground on 6 September 2015, 13:00 UTC. (b) Wind speed at 975 mbar from the NCEP final analysis (FNL) dataset on 6 September 2015, 06:00 UTC. The white rectangle indicates the location of the model domain shown in (a). (c) Model 1000-700 mbar thickness (dam) on 6 September 2015, 15:00 UTC. 

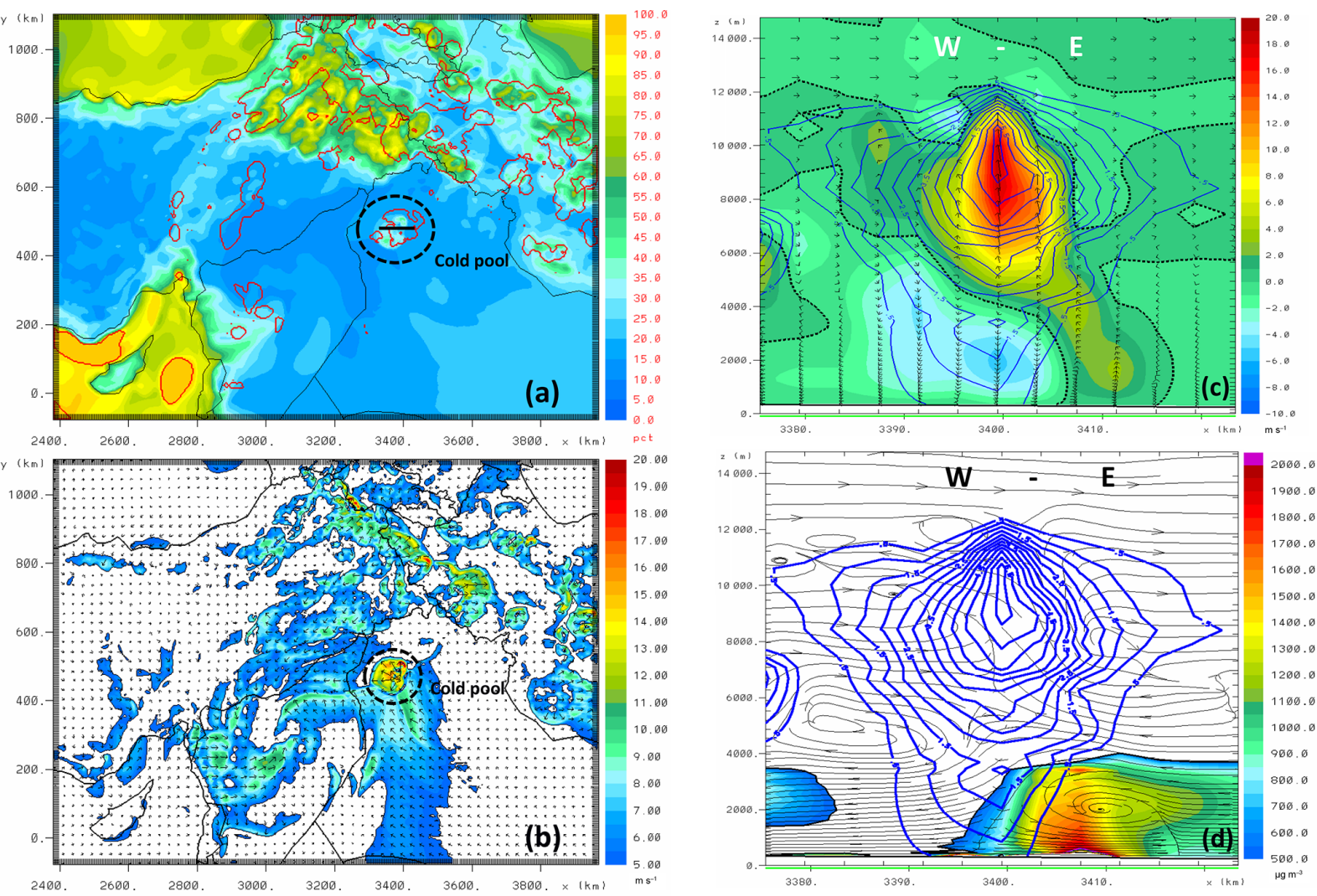

Figure 7. (a) Model relative humidity at the first model level (colour scale) and rain droplet-ambient air difference $\left(-20^{\circ} \mathrm{C}\right.$ shown by red

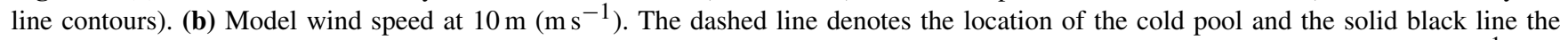
location of the storm cross sections of (c) and (d). (c) Vertical cross section of total condensate mixing ratio (blue contours in $\mathrm{g} \mathrm{kg}^{-1}$ ) and vertical wind component (vectors and colour scale in $\mathrm{m} \mathrm{s}^{-1}$ ). The dashed line separates updraft (positive $w$ ) from downdraft/precipitating regions (negative $w$ ). (d) Vertical cross section of total condensate mixing ratio (blue contours in $\mathrm{g} \mathrm{kg}^{-1}$ ), dust concentration $\left(\mu \mathrm{g} \mathrm{m}{ }^{-3}\right.$ ), and flow streamlines on 6 September 2015, 15:00 UTC.

$-20^{\circ} \mathrm{C}$ between rain droplets and ambient air temperature clearly defines the cold pool area. Subsaturated air below the cloud base is also evident in Fig. 7a, since the relative humidity at the first model layer is between 15 and $20 \%$. The combination of subsaturated air and the temperature gradient results in a faster evaporation rate of the rain droplets and in the formation of a cold pool at the area of northern Iraq, with speeds ranging from 10 up to $20 \mathrm{~m} \mathrm{~s}^{-1}$ (Fig. 7b). As seen in Fig. 7c, the convective cloud top reaches $12 \mathrm{~km}$ and the updrafts exceed $18 \mathrm{~m} \mathrm{~s}^{-1}$ at 15:00 UTC. The rainfall curtain (downdraft area in Fig. 7c) extends up to $4-5 \mathrm{~km}$, and the severity of the storm leads to the formation of a haboob that is evident by the streamline structure and dust production below the non-precipitating parts of the cloud in Fig. 7d. A Kelvin-Helmholtz billow at $2-3 \mathrm{~km}$ separates the density current head from the ambient flow, similar to previous findings for convective haboobs (Solomos et al., 2012). Turbulence distributes the dust particles inside the system, and dust concentrations exceed $2000 \mu \mathrm{g} \mathrm{m}^{-3}$ close to the surface. As the cold pool moves towards the north, it triggers the generation of secondary convective cells at the mountainous ar- eas along the Iran-Iraq-Turkey border. At 20:00 UTC, a series of convective outflows converges in an organized SEpropagating density current that is evident in the model over N Iraq and N Syria (Fig. 8a). This system is characterized by wind speeds higher than $6 \mathrm{~m} \mathrm{~s}^{-1}$ and results in activation of dust sources and near-surface modelled concentrations largely exceeding $10000 \mathrm{\mu g} \mathrm{m}^{-3}$ (Fig. 8b). However, the corresponding SEVIRI image (Fig. 8c) indicates that by this time, the haboob has already penetrated about $200 \mathrm{~km}$ inside Syria, which is not reproduced by the model. The latency between the satellite and modelled haboob fronts is possibly attributed to a slower propagating modelled haboob or to a triggering delay of convection in the model due to the imperfect representation of boundary layer properties and atmospheric stability. 

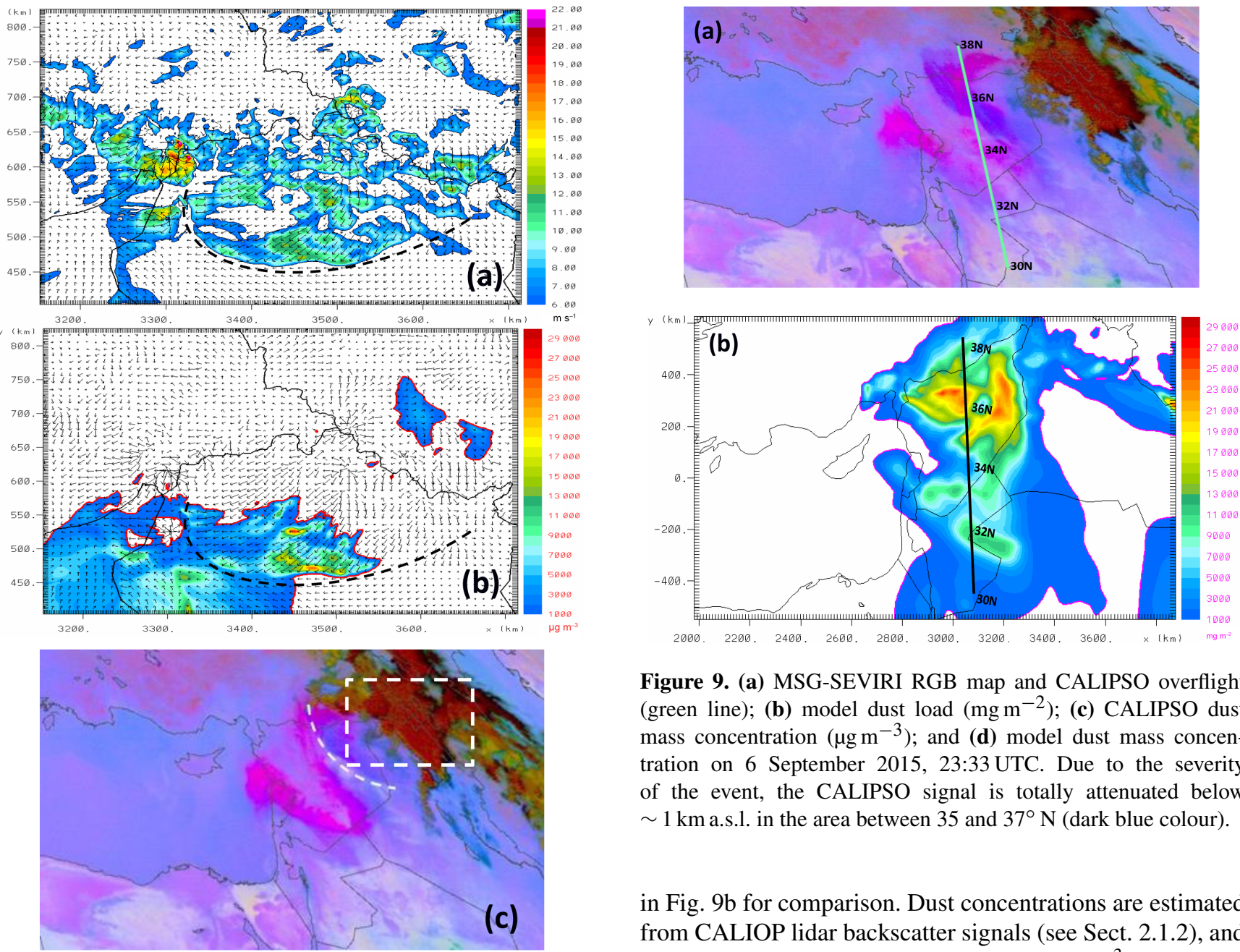

Figure 9. (a) MSG-SEVIRI RGB map and CALIPSO overflight (green line); (b) model dust load $\left(\mathrm{mg} \mathrm{m}^{-2}\right)$; (c) CALIPSO dust mass concentration $\left(\mu \mathrm{g} \mathrm{m}^{-3}\right)$; and (d) model dust mass concentration on 6 September 2015, 23:33 UTC. Due to the severity of the event, the CALIPSO signal is totally attenuated below $\sim 1 \mathrm{~km}$ a.s.1. in the area between 35 and $37^{\circ} \mathrm{N}$ (dark blue colour).

Figure 8. (a) Model wind speed greater than $6 \mathrm{~ms}^{-1}$ at $10 \mathrm{~m}$ and (b) near-surface model dust concentration $\left(\mu \mathrm{g} \mathrm{m}^{-3}\right)$ from the inner grid $(2 \mathrm{~km} \times 2 \mathrm{~km})$. (c) MSG-SEVIRI RGB component on 6 September 2015, 20:00 UTC. The dashed lines indicate the haboob front location, and the dashed rectangle in (c) approximately indicates the location of the model domains shown in (a) and (b).

\subsection{Dust cloud properties and comparison with observations}

\subsubsection{Vertical dust structure}

The dust layer structure as it propagates towards the Mediterranean is captured by two CALIPSO overpasses at 23:33 UTC, 6 September 2015 (Fig. 9), and at 10:35 UTC, 7 September 2015 (Fig. 10). Collocated model cross sections of dust and MSG-SEVIRI dust images are also presented in Figs. 9 and 10. All heights in satellite and model profiles refer to heights above surface. On the 6 September overpass, the southern part of the dust layer $\left(31-34^{\circ} \mathrm{N}\right)$ is detected up to $2-3 \mathrm{~km}$ and originates from the cyclonic flow over Syria (Fig. 9c). The modelled dust load is also shown 

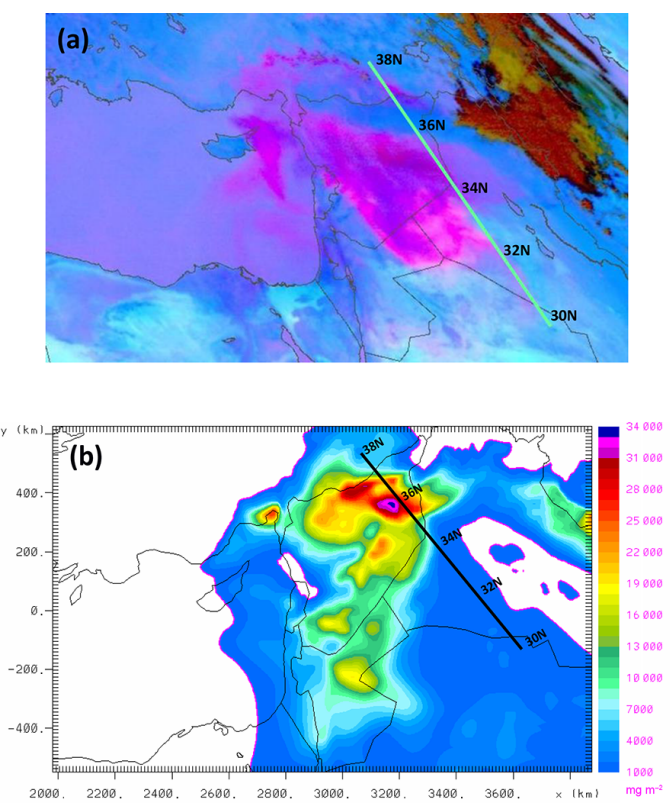

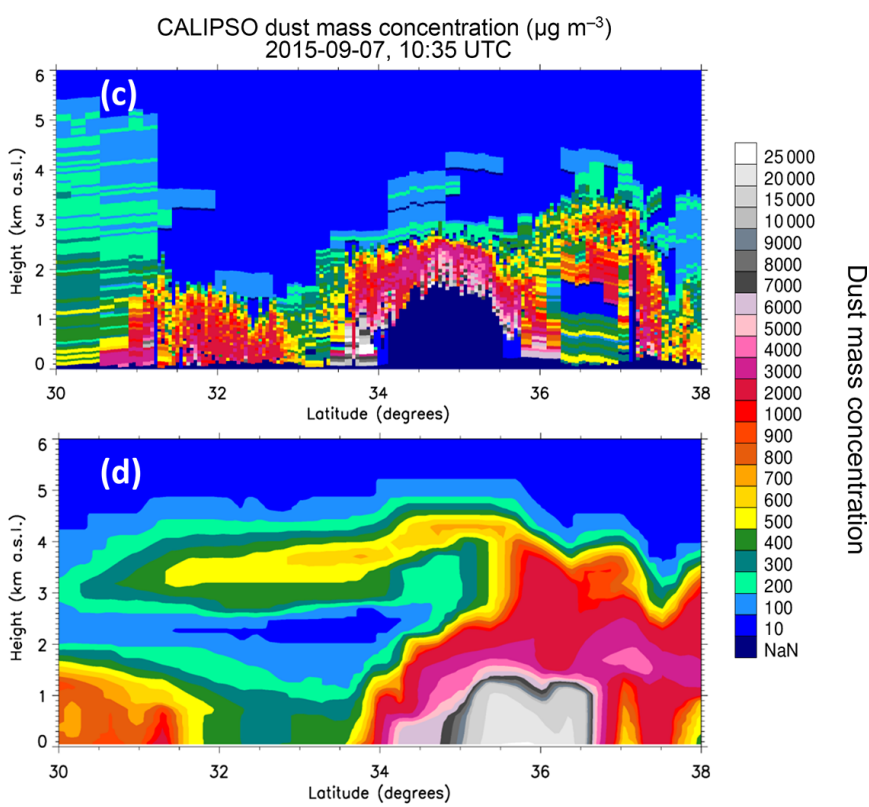

Figure 10. (a) MSG-SEVIRI RGB map and CALIPSO overflight (green line); (b) model dust load (mg m ${ }^{-2}$ ); (c) CALIPSO dust mass concentration $\left(\mu \mathrm{g} \mathrm{m}^{-3}\right)$; and (d) model dust mass concentration on 7 September 2015, 10:35 UTC. Due to the severity of the event CALIPSO signal is totally attenuated below $\sim 1 \mathrm{~km}$ a.s.l. in the area between 34 and $36^{\circ} \mathrm{N}$ (dark blue colour).

The second overpass on 7 September, 10:35 UTC, is actually behind or at the tail of the propagating dust storm (Fig. 10a). The modelled dust load is also shown in Fig. 10b for comparison. The thin dust layer that is detected by CALIPSO between 30 and $32^{\circ} \mathrm{N}$ reaches up to $2 \mathrm{~km}$, and maximum dust concentrations of up to $2000-3000 \mu \mathrm{g} \mathrm{m}^{-3}$ are calculated mostly close to the surface (Fig. 10c). Extreme dust concentrations are also found in both satellite (Fig. 10c) and model plots (Fig. 10d) between 34 and $36^{\circ} \mathrm{N}$ at the tail of the propagating system. Dust values at this area are so high that the CALIPSO observation again suffers from a total attenuation of the lidar signal after penetrating the first $1000 \mathrm{~m}$ and extraordinary concentrations of up to $20000 \mu \mathrm{g} \mathrm{m}^{-3}$ are found in the lower model levels (up to $1.5 \mathrm{~km}$ ). Similar values are observed from CALIPSO at the edge of the haboob $\left(33.5-34^{\circ} \mathrm{N}\right)$, where the signal is strong enough to provide valuable information. The elevated layers $(2-4 \mathrm{~km})$ between 36 and $38^{\circ} \mathrm{N}$, on both CALIPSO and the model profiles, are dust residuals over the mountains of Turkey. An elevated dust layer of up to $600 \mu \mathrm{g} \mathrm{m}^{-3}$ is also found south of $35^{\circ} \mathrm{N}$ in the model at heights between 3 and $4 \mathrm{~km}$. Due to the aforementioned latency between the true and modelled propagation speeds, the model cross section is closer to the core of the system; hence, this layer consists of modelled cyclone uplifted dust that is in fact already west of the CALIPSO ground track.

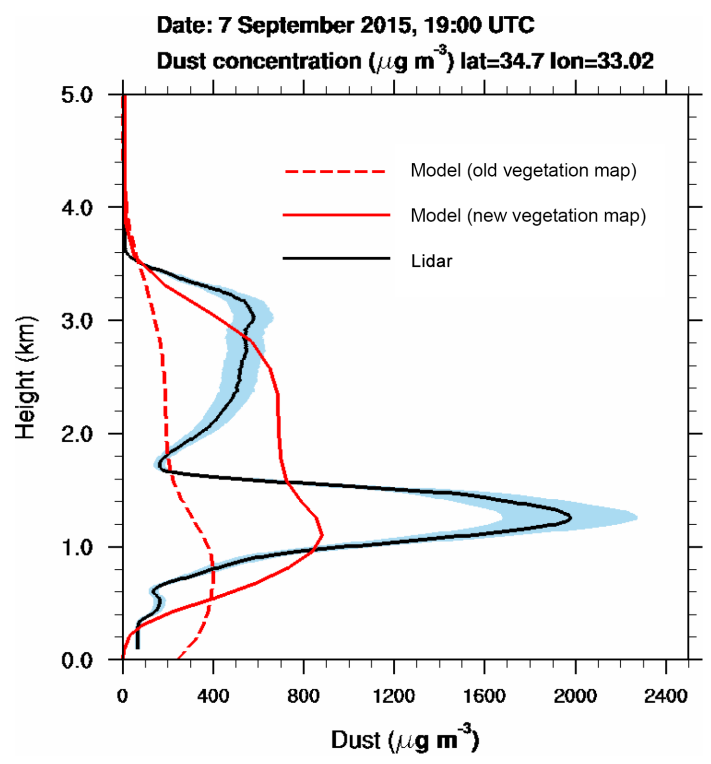

Figure 11. Vertical profile of dust concentration over Limassol on 7 September, 19:00 UTC. The blue shadow indicates a 20\% uncertainty in the lidar measurements.

\subsubsection{Dust load over Cyprus}

The observed structure and amounts of dust arriving in Cyprus are described in detail by Mamouri et al. (2016). The arrival of the dust plumes at Limassol in Cyprus is evident in Fig. 11. A double-layer structure is detected by the lidar on 7 September, 19:00 UTC. The relatively shallow dust 

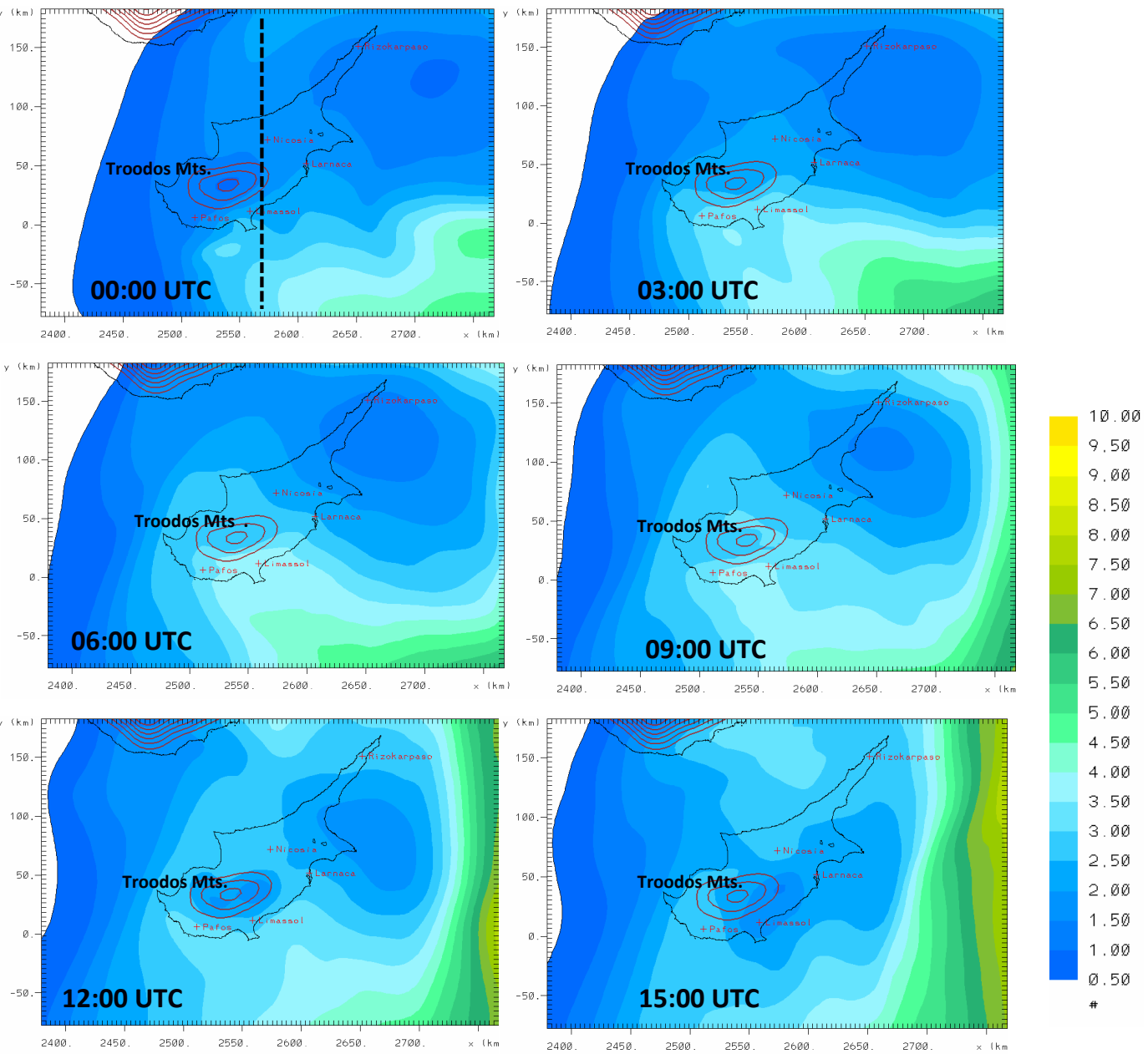

Figure 12. Model $550 \mathrm{~nm}$ AOT over Cyprus during 00:00-15:00 UTC, 8 September 2015; zoom from the second $(4 \mathrm{~km} \times 4 \mathrm{~km})$ model domain. The dashed black line shows the location of the cross sections in Fig. 13.

layer that is found between 0.8 and $1.7 \mathrm{~km}$, with a maximum peak at $2000 \mu \mathrm{g} \mathrm{m}^{-3}$, comes from the detached dust air mass travelling off the coast of Lebanon as described in Sect. 3.1.1. The model correctly reproduces the height of this layer, but the maximum concentration is underestimated by almost $50 \%$. The upper layer that is detected between 1.8 and $3.6 \mathrm{~km}$ originates from the northern part of the rapidly propagating haboob that catches up with the Lebanon dust over Cyprus. The location and dust concentrations of this layer are adequately reproduced by the model. The total modelled dust load is similar to the observed (lidar) dust load, but the vertical distribution of dust in two distinct layers is not so clearly reproduced. Model results using the old vegetation database are also shown in Fig. 11. As seen by the dashed line in this plot, this simulation failed to reproduce the strength of the event, and the maximum concentration is $400 \mu \mathrm{g} \mathrm{m}^{-3}$ at about $0.7 \mathrm{~km}$ height. On 8 September the lidar system could not operate due to the extraordinary dust load. The mean MODIS-derived AOT on this day varied between 1.5 and 5 over five sites in Cyprus (Pafos, Limassol, Larnaca, Nicosia, Rizokarpaso) (Mamouri et al., 2016). Given the fact that the maximum retrievable MODIS AOT is 5, these values are most probably an underestimation of the true AOT. The distribution of the modelled AOT during 00:00-15:00 UTC on 8 September is shown in Fig. 12; the dust plume approaches Cyprus from the south and the orographic effect of the Troodos mountains results in an inhomogeneous distribution of dust load over the island, which explains the AOT variability between the sites. The modelled AOT values over the Middle East inland exceed 10, as shown by the sharp gradient towards the eastern part of the Fig. 12 plots. However, the extreme dust storm affecting Cyprus during 8 September is the result of a plume that approaches the island from the south. This dust layer is evident between 1.5 and $3.5 \mathrm{~km}$ in the vertical cross sections of the model dust concentration at 00:00 and 03:00 UTC in Fig. 13. Differential heating between the land and water bodies and between flat terrain and mountain slopes results in the development of local 

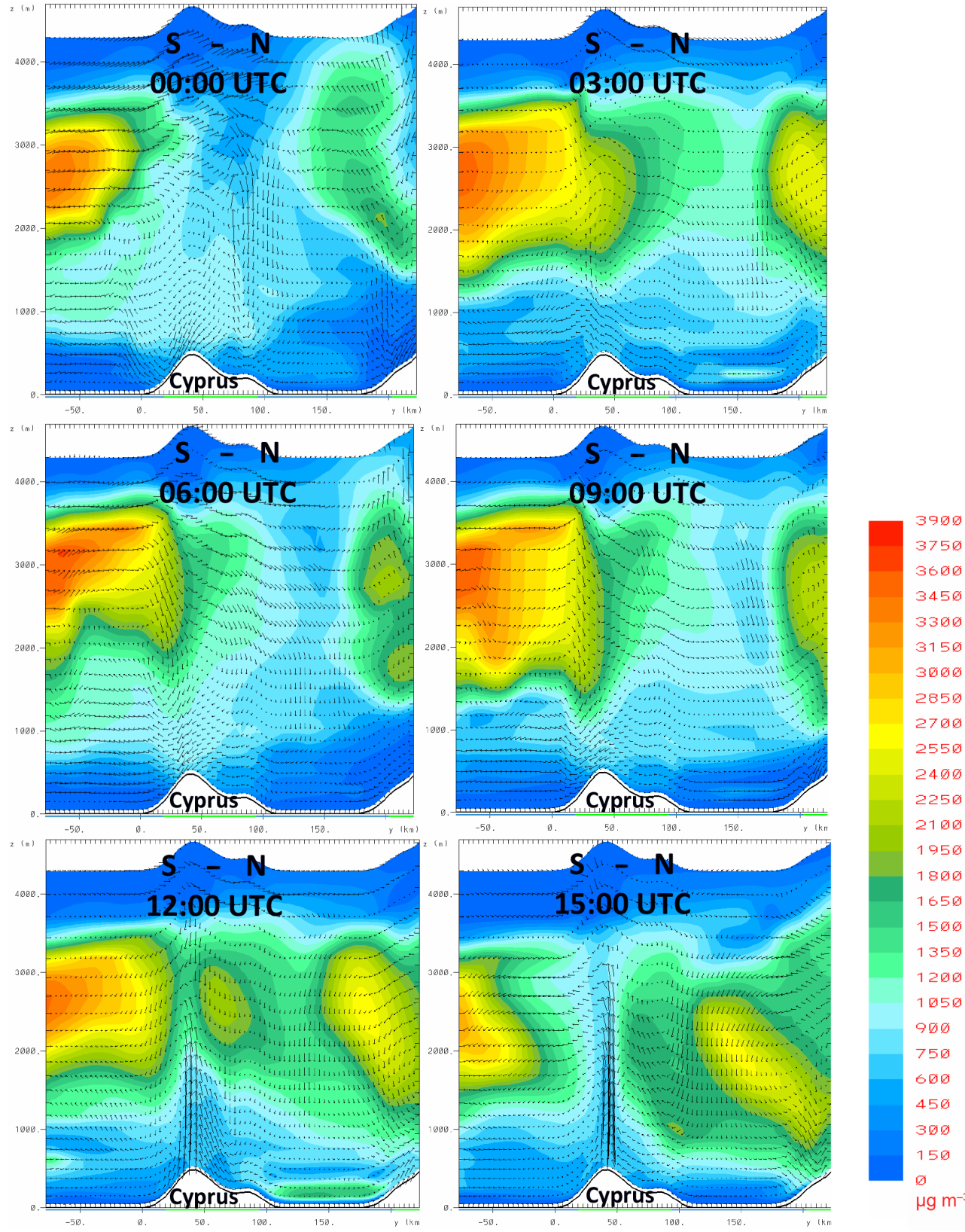

Figure 13. Vertical cross section (south-north) of modelled dust concentration over Cyprus during 00:00-15:00 UTC on 8 September 2015. The location of the cross section is shown in Fig. 12.

wind flows (downslope and upslope winds). The downward mixing of dust as this air mass approaches the topographic barrier of the Troodos mountains increases the near-surface concentrations at the southern sites especially during local morning and noon hours (06:00, 09:00 UTC). In the afternoon hours (12:00, 15:00 UTC), the development of upward motions over the Troodos mountains separates the dust flow over Cyprus into two distinct cells (a south and a north one), and at this time increased concentrations are found over the northern sites of the island. The maximum simulated concen- trations are up to $4000 \mu \mathrm{g} \mathrm{m}^{-3}$ aloft and about $1000 \mu \mathrm{g} \mathrm{m}^{-3}$ close to the surface.

Taking into account the complexity of the situation, the spatiotemporal evolution of the episode seems to be correctly explained by the model, but the extreme values of 8000 $10000 \mathrm{mg} \mathrm{m}^{-3}$ that are reported by Mamouri et al. (2016) are not reproduced. This discrepancy can be attributed to a variety of reasons related to both dust and atmospheric properties that are not properly resolved at this model scale (e.g. more intense downward mixing, increased emissions 
Table 2. Maximum MODIS and RAMS AOT over Cyprus (8 September 2015).

\begin{tabular}{lccccc}
\hline & Pafos & Limassol & Larnaca & Nicosia & Rizokarpaso \\
\hline MODIS $_{\text {AOT }}$ & 3.5 & 5.0 & 5.0 & 2.0 & 5.0 \\
RAMS $_{\text {AOT }}$ & 3.5 & 4.0 & 3.0 & 3.0 & 3.0 \\
\hline
\end{tabular}

from the sources, limitations due to emission size bins, and inaccurate deposition rates). The simulated versus observed maximum AOT values for the five sites are also shown in Table 2. The model reproduces the higher AOTs at the most southern sites (Limassol and Pafos) compared to the central and northern sites. Following the previous discussion about the already underestimated MODIS AOT, it seems that the model reproduces the distribution of dust over Cyprus, however, with an overall underestimation of more than 2. A possible explanation could also be that the dry river beds of the Tigris and Euphrates, as well as the several dust sources over Syria and northern Iraq, provide even more erodible sediments than those assumed by the model, hence the discrepancies in dust concentrations.

\section{Discussion and conclusions}

A combination of meteorological and land-use conditions resulted in the formation of an unprecedented dust episode over the Middle East and the eastern Mediterranean during 6-11 September 2015. This event is unique due to the coincidence of various atmospheric phenomena related to the generation of turbulence and dust production. Interpretation and analysis of remote sensing data (EARLINET, CALIPSO, and MSG-SEVIRI) and modelling simulations (RAMS-ICLAMS) reveals the main reasons that led to the uplift and persistence of the dust layers.

The major processes affecting the generation of the dust storm were found to be

1. the formation of a strong thermal low and of convective outflows over Syria that lifted dust up to $4 \mathrm{~km}$,

2. the intrusion of moist and unstable air masses from the Arabian Sea and the Red Sea that triggered convective activity over the Iraq-Iran-Syria-Turkey border,

3. the generated outflow boundaries that led to dust deflation and formed a westward-propagating haboob that merged with the previously elevated dust over Syria, and

4. the increased efficiency of Middle East dust sources in the aftermath of war and the related changes in land use.

As reported by Mamouri et al. (2016), almost all operational dust models failed to forecast this event. RAMS-ICLAMS in this study is not used in forecasting mode, but rather as a tool for the a posteriori analysis and explanation of the event. This means that the configuration of several model parameters, such as the nested grid structure, convective parameterization schemes, and dust source strength, is guided by the available observations. In this context, most observed processes are successfully described by the model and the various physical mechanisms that took place during the event are explained. However, certain inaccuracies in the quantification of atmospheric variables and spatiotemporal deviations in the description of convection and other physical processes can still significantly decrease the model skill, especially regarding the quantification of dust mass profiles.

The analysis presented here raises considerations regarding the forecast skill of the atmospheric dust models, since even though such extreme episodes are seldom, they still represent the most threatening dust hazards. The long-range transport and the general circulation of dust in the atmosphere are now often adequately forecasted by most global models, but convectively driven episodes cannot be resolved at synoptic and mesoscale resolutions. Moreover, a recent study by Pope et al. (2016) at the area of the Sahel, or southern Sahara, suggests that unresolved haboobs during the summer monsoon may be responsible for up to $30 \%$ of the total atmospheric dust, and such considerations raise questions on the current status of early warning systems for dust episodes. It is probably obvious that such a system cannot rely exclusively on modelling simulations. As shown in the present study, the complexity of these events makes forecasting them very challenging, and it is possible that a certain model configuration could successfully reproduce a specific event but not all similar events. The key to forecasting these events in atmospheric models is the use of cloud-resolving grid space. However, such high-resolution grid space can only be applied over limited areas due to restrictions in computational power. Forthcoming studies using an extended cloud-resolving grid over the entire Middle East (e.g. Gasch et al., 2017) could provide more detail on the individual atmospheric processes during this episode.

Remote sensing can play an important role for the provision of more accurate dust forecasts. The engagement of geostationary satellite observations (MSG, Sentinel-4) and CALIPSO profiles in forecasting activities could improve the forecasting skill, either by the direct assimilation of satellite data in dust models or by issuing human-assisted early warnings. The expansion of a lidar network close to dust source areas (e.g. Sahara and the Middle East) could also complement model activities through the provision of ground truth observations for the vertical profile of dust plumes. Additionally, the activation of correlated observations from the EARLINET network following a dust forecast notice could allow a closer investigation of the physical processes that drive these events. 
Data availability. The lidar profiles can be downloaded from the ACTRIS data base at http://actris.nilu.no (ACTRIS/EARLINET, 2016). The CALIPSO data are available at the NASA Atmospheric Science Data Center (ASDC; CALIPSO Science Team, 2015a, b) and at the online archive of the ICARE Data and Services center, http://www.icare.univ-lille1.fr/archive (ICARE Data Center, 2017a, b). The data used to calculate the NDVI time series in Fig. 3 are available through the NASA EOSDIS Land Processes Distributed Active Archive Center (LP DAAC) (Schaaf, 2015) and can also be obtained through Google Earth Engine (Google Earth Engine Team, 2015). The MSG-SEVIRI imagery can be obtained through the ICARE data center (http://www.icare.univ-lille1.fr/browse/geoview.php? dataset=seviri_dust\&slot=201509071300). The RAMS simulation data used in this work are available upon request from Stavros Solomos (stavros@noa.gr).

Competing interests. The authors declare that they have no conflict of interest.

Acknowledgements. The authors acknowledge support through the following projects and research programmes: BEYOND under grant agreement no. 316210 of the European Union Seventh Framework Programme FP7-REGPOT-2012-2013-1; ACTRIS-2 under grant agreement no. 654109 of the European Union's Horizon 2020 research and innovation programme; ECARS under grant agreement no. 602014 from the European Union's Horizon 2020 Research and Innovation programme; and MarcoPolo under grant agreement no. 606953 of the European Union Seventh Framework Programme FP7/2007-2013. The authors acknowledge EARLINET for providing aerosol lidar profiles available under the World Data Center for Climate (WDCC; the EARLINET publishing group 2000-2010, 2014). CALIPSO data were obtained from the ICARE Data Center (http://www.icare.univ-lille1.fr/) and from the NASA Langley Research Center Atmospheric Science Data Center. CALIPSO data were provided by NASA. We thank the ICARE Data and Services Center and their computational centre for providing access to the data used in this study. The authors acknowledge the use of Google Earth Engine for the data analyses in Figs. 2 and 3 (Google Earth Engine Team, 2015).

Edited by: M. Tesche

Reviewed by: four anonymous referees

\section{References}

ACTRIS/EARLINET: EARLINET aerosol lidar profiles, available at: http://actris.nilu.no, last access: October 2016.

Ansmann A., Tesche, M., Knipperts, P., Bierwirth, E., Althausen, D., Muller, D., and Schulz, O.: Vertical profiling of convective dust plumes in southern Morocco during SAMUM, Tellus B, 61, 340-353, doi:10.1111/j.1600-0889.2008.00384.x, 2009.

Ansmann, A., Petzold, A., Kandler, K., Tegen, I., Wendisch, M., Müller, D., Weinzierl, B., Müller, T., and Heintzenberg, J.: Saharan Mineral Dust Experiments SAMUM-1 and SAMUM-2: what have we learned?, Tellus B, 63, 403-429, 2011.
Ansmann, A., Seifert, P., Tesche, M., and Wandinger, U.: Profiling of fine and coarse particle mass: case studies of Saharan dust and Eyjafjallajökull/Grimsvötn volcanic plumes, Atmos. Chem. Phys., 12, 9399-9415, doi:10.5194/acp-12-9399-2012, 2012.

Banks, J. R. and Brindley, H. E.: Evaluation of MSGSEVIRI mineral dust retrieval products over North Africa and the Middle East, Remote Sens. Environ., 128, 58-73, doi:10.1016/j.rse.2012.07.017, 2013.

Barahona, D. and Nenes, A.: Parameterizing the competition between homogeneous and heterogeneous freezing in ice cloud formation-polydisperse ice nuclei, Atmos. Chem. Phys., 9, 5933-5948, doi:10.5194/acp-9-5933-2009, 2009.

Barahona, D., West, R. E. L., Stier, P., Romakkaniemi, S., Kokkola, H., and Nenes, A.: Comprehensively accounting for the effect of giant CCN in cloud activation parameterizations, Atmos. Chem. Phys., 10, 2467-2473, doi:10.5194/acp-10-2467-2010, 2010.

Benedetti, A., Morcrette, J.-J., Boucher, O., Dethof, A., Engelen, R. J., Fisher, M., Flentje, H., Huneeus, N., Jones, L., Kaiser, J. W., Kinne, S., Mangold, A., Razinger, M., Simmons, A. J., and Suttie, M.: Aerosol analysis and forecast in the European Centre for Medium-Range Weather Forecasts Integrated Forecast System: 2. Data assimilation, J. Geophys. Res., 114, D13205, doi:10.1029/2008JD011115, 2009.

Bou Karam, D., Flamant, C., Knippertz, P., Reitebuch, O., Pelon, J., Chong, M., and Dabas, A: Dust emissions over the Sahel associated with the West African Monsoon inter-tropical discontinuity region: a representative case study, Q. J. Roy. Meteorol. Soc., 134, 621-634, 2008.

Brindley, H., Knippertz, P., Ryder, C., and Ashpole, I.: A critical evaluation of the ability of the Spinning Enhanced Visible and Infrared Imager (SEVIRI) thermal infrared red-green-blue rendering to identify dust events: Theoretical analysis, J. Geophys. Res., 117, D07201, doi:10.1029/2011JD017326, 2012.

CALIPSO Science Team: CALIPSO/CALIOP Level 2, Lidar Aerosol Profile Data, version 3.30, Hampton, VA, USA, NASA Atmospheric Science Data Center (ASDC), doi:10.5067/CALIOP/CALIPSO/CAL_LID_L2_05kmAProProv-V3-30_L2-003.30, 2015a.

CALIPSO Science Team: CALIPSO/CALIOP Level 2, Lidar Cloud Profile Data, version 3.30, Hampton, VA, USA, NASA Atmospheric Science Data Center (ASDC), doi:10.5067/CALIOP/CALIPSO/CAL_LID_L2_05kmCProProv-V3-30_L2-003.30, 2015b.

Cook, B. I., Anchukaitis, K. J., Touchan, R., Meko, D. M., and Cook, E. R.: Spatiotemporal drought variability in the Mediterranean over the last 900 years, J. Geophys. Res.-Atmos., 121, 2060-2074, doi:10.1002/2015JD023929, 2016.

Cotton, W. R., Pielke Sr., R. A., Walko, R. L., Liston, G. E., Tremback, C. J., Jiang, H., McAnelly, R. L., Harrington, J. Y., Nicholls, M. E., Carrio, G. G., and McFadden, J. P.: RAMS 2001: Current status and future directions, Meteorol. Atmos. Phys., 82, 5-29, 2003.

DeFries, R. S. and Townshend, J. R. G.: NDVI-derived land cover classifications at a global scale, Int. J. Remote Sens., 15, 35673586, doi:10.1080/01431169408954345, 1994.

Dempseym M. J.: Forecasting Strategies for Haboobs: An Underreported Weather Phenomenon, Adv. Meteorol., 2014, 904759, doi:10.1155/2014/904759, 2014. 
Didan, K.: MOD13A3 MODIS/Terra vegetation Indices Monthly L3 Global $1 \mathrm{~km}$ SIN Grid V006, NASA EOSDIS Land Processes DAAC, doi:10.5067/MODIS/MOD13A3.006, 2015.

EARLINET publishing group 2000-2010: Adam, M., AladosArboledas, L., Althausen, D., Amiridis, V., Amodeo, A., Ansmann, A., Apituley, A., Arshinov, Y., Balis, D., Belegante, L., Bobrovnikov, S., Boselli, A., Bravo-Aranda, J. A., Bösenberg, J., Carstea, E., Chaikovsky, A., Comerón, A., D’Amico, G., Daou, D., Dreischuh, T., Engelmann, R., Finger, F., Freudenthaler, V., Garcia-Vizcaino, D., García, A. J. F., Geiß, A., Giannakaki, E., Giehl, H., Giunta, A., de Graaf, M., Grana-dosMuñoz, M. J., Grein, M., Grigorov, I., Groß, S., Ruening, C., Guerrero-Rascado, J. L., Haeffelin, M., Hayek, T., Iarlori, M., Kanitz, T., Kokkalis, P., Linné, H., Madonna, F., Mamouri, R.E., Matthias, V., Mattis, I., Menéndez, F. M., Mitev, V., Mona, L., Morille, Y., Muñoz, C., Müller, A., Müller, D., Navas-Guzmán, F., Nemuc, A., Nicolae, D., Pandolfi, M., Papayannis, A., Pappalardo, G., Pelon, J., Perrone, M. R., Pietruczuk, A., Pisani, G., Potma, C., Preißler, J., Pujadas, M., Putaud, J., Radu, C., Ravetta, F., Reigert, A., Rizi, V., Rocadenbosch, F., Rodríguez, A., Sauvage, L., Schmidt, J., Schnell, F., Schwarz, A., Seifert, P., Serikov, I., Sicard, M., Silva, A. M., Simeonov, V., Siomos, N., Sirch, T., Spinelli, N., Stoyanov, D., Talianu, C., Tesche, M., De Tomasi, F., Trickl, T., Vaughan, G., Volten, H., Wagner, F., Wandinger, U., Wang, X., Wiegner, M., and Wilson, K. M.: EARLINET all observations (2000-2010), World Data Center for Climate (WDCC), doi:10.1594/WDCC/EN_all_measurements_ 2000-2010, 2014.

Emmel, C., Knippertz, P., and Schulz, O.: Climatology of convective density currents in the southern foothills of the Atlas mountains, J. Geophys. Res., 115, D11115, doi:10.1029/2009JD011819, 2010.

Fountoukis, C. and Nenes, A.: Continued Development of a Cloud Droplet Formation Parameterization for Global Climate Models, J. Geophys. Res., 110, D11212, doi:10.1029/2004JD005591, 2005.

Fountoukis, C., Nenes, A., Meskhidze, N., Bahreini, R., Conant, W. C., Jonsson, H., Murphy, S., Sorooshian, A., Varutbangkul, V., Brechtel, F., Flagan, R. C., and Seinfeld, J. H.: Aerosol-cloud drop concentration closure for clouds sampled during the International Consortium for Atmospheric Research on Transport and Transformation 2004 campaign, J. Geophys. Res., 112, D10S30, doi:10.1029/2006JD007272, 2007.

Gasch, P., Rieger, D., Walter, C., Khain, P., Levi, Y., and Vogel, B.: An analysis of the September 2015 severe dust event in the Eastern Mediterranean, Atmos. Chem. Phys. Discuss., doi:10.5194/acp-2017-11, in review, 2017.

Ginoux, P., Prospero, J. M., Gill, T. E., Hsu, N. C., and Zhao, M.: Global-scale attribution of anthropogenic and natural dust sources and their emission rates based on MODIS Deep Blue aerosol products, Rev. Geophys., 50, RG3005, doi:10.1029/2012RG000388, 2012.

Gong, S. L.: A parameterization of sea-salt aerosol source function for sub- and super-micron particles, Global Biogeochem. Cy., 17, 1097, doi:10.1029/2003GB002079, 2003.

Gong, S. L., Barrie, L. A., and Lazare, M.: Canadian Aerosol Module (CAM): a size-segregated simulation of atmospheric aerosol processes for climate and air quality models. 2. Global seasalt aerosol and its budgets, J. Geophys. Res., 107, 4779, doi:10.1029/2001JD002004, 2002.

Google Earth Engine Team: Google Earth Engine: A planetaryscale geospatial analysis platform, https://earthengine.google. com (last access: March 2017), 2015.

Iacono, M. J., Mlawer, E. J., Clough, S. A., and Morcrette, J. J.: Impact of an improved longwave radiation model, RRTM, on the energy budget and thermodynamic properties of the NCAR Community Climate Model, CCM3, J. Geophys. Res., 105, 1487314890, 2000.

ICARE Data Center: CALIPSO/CALIOP Level 2, Lidar Aerosol Profile Data, version 3.30, file CAL_LID_L2_05kmAProProv-V3-30.2015-09-07T10-04-10ZD.hdf, available at: http://www.icare.univ-lille1.fr/drupal/archive_file/download. php?file=CALIOP/05kmAPro.v3.30/2015/2015_09_07/CAL_ LID_L2_05kmAPro-Prov-V3-30.2015-09-07T10-04-10ZD.hdf (last access: 22 March 2017), 2017a.

ICARE Data Center: CALIPSO/CALIOP Level 2, Lidar Cloud Profile Data, version 3.30, file CAL_LID_L2_05kmCProProv-V3-30.2015-09-07T10-04-10ZD.hdf, available at: http://www.icare.univ-lille1.fr/drupal/archive_file/download. php?file=CALIOP/05kmCPro.v3.30/2015/2015_09_07/CAL_ LID_L2_05kmCPro-Prov-V3-30.2015-09-07T10-04-10ZD.hdf (last access: 22 March 2017), 2017 b.

Jaafar, H. H. and Woertz, E.: Agriculture as a funding source of ISIS: A GIS and remote sensing analysis, Food Policy, 64, 14 25, doi:10.1016/j.foodpol.2016.09.002, 2016.

Kain, J. S. and Fritsch, J. M.: Convective parameterization for mesoscale models: the Kain-Fritsch scheme. The Representation of Cumulus Convection in Numerical Models, Meteor. Monogr. No. 46. Amer. Meteor. Soc., 165-170, 1993.

Knippertz, P., Trentmann, J., and Seifert, A.: High resolution simulations of convective cold pools over the northwestern Sahara, J. Geophys. Res., 114, D21109, doi:10.1029/2007JD008774, 2009.

Leeuw, G., Neele, F. P., Hill, M., Smith, M. H., and Vignali, E.: Production of sea spray aerosol in the surf zone, J. Geophys. Res.Atmos., 105, 29397-29409, 2000.

Lensky, I. M. and Rosenfeld, D.: Clouds-Aerosols-Precipitation Satellite Analysis Tool (CAPSAT), Atmos. Chem. Phys., 8, 6739-6753, doi:10.5194/acp-8-6739-2008, 2008.

Mamouri, R. E. and Ansmann, A.: Fine and coarse dust separation with polarization lidar, Atm. Meas. Tech., 7, 3717-3735, doi:10.5194/amt-7-3717-2014, 2014.

Mamouri, R. E., Ansmann, A., Nisantzi, A., Kokkalis, P., Schwarz, A., and Hadjimitsis, D.: Low Arabian dust extinctiontobackscatter ratio, Geophys. Res. Lett., 40, 4762-4766, doi:10.1002/grl.50898, 2013.

Mamouri, R.-E., Ansmann, A., Nisantzi, A., Solomos, S., Kallos, G., and Hadjimitsis, D. G.: Extreme dust storm over the eastern Mediterranean in September 2015: satellite, lidar, and surface observations in the Cyprus region, Atmos. Chem. Phys., 16, 13711-13724, doi:10.5194/acp-16-13711-2016, 2016.

Marsham, J. H., Dixon, N. S., Garcia-Carreras, L., Lister, G. M. S., Parker, D. J., Knippertz, P., and Birch, C. E.: The role of moist convection in the West African monsoon system: Insights from continental-scale convection-permitting simulations, Geophys. Res. Lett., 40, 1843-1849, doi:10.1002/grl.50347, 2013. 
Marticorena, B. and Bergametti, G.: Modeling the atmospheric dust cycle: 1 . Design of a soil derived dust emission scheme, J. Geophys. Res., 100, 16415-16430, 1995.

Meyers, M. P., Walko, R. L., Harrington, J. Y., and Cotton, W. R.: New RAMS cloud microphysics parameterization. Part II: The two-moment scheme, Atmos. Res., 45, 3-39, 1997.

Mlawer, E. J., Taubman, S. J., Brown, P. D., Iacono, M. J., and Clough, S. A.: Radiative transfer for inhomogeneous atmospheres: RRTM, a validated correlated- $k$ model for the longwave, J. Geophys. Res., 102, 16663-16682, 1997.

Mona L., Liu, Z., Müller, D., Omar, A., Papayannis, A., Pappalardo, G., Sugimoto, N., and Vaughan, M.: Lidar Measurements for Desert Dust Characterization: An Overview, Adv. Meteorol., 2012, 356265, doi:10.1155/2012/356265, 2012.

Monahan, E. C., Spiel, D. E., and Davidson, K. L.: A model of marine aerosol generation via whitecaps and wave disruption, in: Oceanic Whitecaps, edited by: Monahan, E. C. and Mac Niocaill, G., D. Reidel, 167-174, doi:10.1007/978-94-009-46682_16, 1986.

Notaro, M., Yu, Y., and Kalashnikova, O. V.: Regime shift in Arabian dust activity, triggered by persistent Fertile Crescent drought, J. Geophys. Res.-Atmos., 120, 10229-10249, doi:10.1002/2015JD023855, 2015.

Pappalardo, G., Amodeo, A., Apituley, A., Comeron, A., Freudenthaler, V., Linné, H., Ansmann, A., Bösenberg, J., D’Amico, G., Mattis, I., Mona, L., Wandinger, U., Amiridis, V., AladosArboledas, L., Nicolae, D., and Wiegner, M.: EARLINET: towards an advanced sustainable European aerosol lidar network, Atmos. Meas. Tech., 7, 2389-2409, doi:10.5194/amt-7-23892014, 2014.

Pantillon, F., Knippertz, P., Marsham, J. H., Panitz, H.-J., and Bischoff-Gauss, I.: Modeling haboob dust storms in large-scale weather and climate models, J. Geophys. Res.-Atmos., 121, 2090-2109, doi:10.1002/2015JD024349, 2016.

Pielke, R. A., Cotton, W. R., Walko, R. L., Tremback, C. J., Lyons, W. A., Grasso, L. D., Nicholls, M. E., Moran, M. D., Wesley, D. A., Lee, T. J., and Copeland, J. H.: A comprehensive meteorological modeling system - RAMS, Meteorol. Atmos. Phys., 49, 69-91, 1992.

Pope, R. J., Marsham, J. H., Knippertz, P., Brooks, M. E., and Roberts, A. J.: Identifying errors in dust models from data assimilation, Geophys. Res. Lett., 43, 9270-9279, doi:10.1002/2016GL070621, 2016.

Prospero, J. M., Ginoux, P., Torres, O., Nicholson, S. E., and Gill, T. E.: Environmental Characterization of Global Sources of Atmospheric Soil Dust Identified with the Nimbus 7 Total Ozone Mapping Spectrometer (toms) Absorbing Aerosol Product, Rev. Geophys., 40, 1002, doi:10.1029/2000RG000095, 2002.

Reinfried, F., Tegen, I., Heinold, B., Hellmuth, O., Schepanski, K., Cubasch, U., Huebener, H., and Knippertz, P.: Simulations of convectively-driven density currents in the Atlas region using a regional model: Impacts on dust emission and sensitivity to horizontal resolution and convection schemes, J. Geophys. Res., 114, D08127, doi:10.1029/2008JD010844, 2009.

Roberts, A. J. and Knippertz, P.: The formation of a large summertime Saharan dust plume: Convective and synopticscale analysis, J. Geophys. Res.-Atmos., 119, 1766-1785, doi:10.1002/2013JD020667, 2014.
Ryder, C. L., McQuaid, J. B., Flamant, C., Rosenberg, P. D., Washington, R., Brindley, H. E., Highwood, E. J., Marsham, J. H., Parker, D. J., Todd, M. C., Banks, J. R., Brooke, J. K., Engelstaedter, S., Estelles, V., Formenti, P., Garcia-Carreras, L., Kocha, C., Marenco, F., Sodemann, H., Allen, C. J. T., Bourdon, A., Bart, M., Cavazos-Guerra, C., Chevaillier, S., Crosier, J., Darbyshire, E., Dean, A. R., Dorsey, J. R., Kent, J., O’Sullivan, D., Schepanski, K., Szpek, K., Trembath, J., and Woolley, A.: Advances in understanding mineral dust and boundary layer processes over the Sahara from Fennec aircraft observations, Atmos. Chem. Phys., 15, 8479-8520, doi:10.5194/acp-15-84792015, 2015.

Schaaf, C. Z. W.: MCD43A4 MODIS/Terra+Aqua BRDF/Albedo Nadir BRDF Adjusted RefDaily L3 Global - 500m V006, NASA EOSDIS Land Processes DAAC, doi:10.5067/MODIS/MCD43A4.006, 2015.

Schepanski, K., Tegen, I., Todd, M. C., Heinold, B., Bonisch, G., Laurent, B., and Macke, A.: Meteorological processes forcing Saharan dust emission inferred from MSG-SEVIRI observations of subdaily dust source activation and numerical models, J. Geophys. Res., 114, D10201, doi:10.1029/2008JD010325, 2009.

Seinfeld, J. H. and Pandis, S. N.: Atmospheric Chemistry and Physics: From Air Pollution to Climate Change, J. Wiley, New York, 1998.

Singh, N., van Zoonen, D., and Khogir, M.: Iraq agriculture and livelihoods needs assessment in the newly liberated areas of Kirkuk, Ninewa and Salahadin, Food and Agricutlure Organization of the United Nations, available at: http://www.fao.org/emergencies/resources/documents/ resources-detail/en/c/386870/ (last access: March 2017), 2016.

Solomos, S., Kallos, G., Kushta, J., Astitha, M., Tremback, C., Nenes, A., and Levin, Z.: An integrated modeling study on the effects of mineral dust and sea salt particles on clouds and precipitation, Atmos. Chem. Phys., 11, 873-892, doi:10.5194/acp11-873-2011, 2011.

Solomos, S., Kallos, G., Mavromatidis, E., and Kushta, J.: Density currents as a desert dust mobilization mechanism, Atmos. Chem. Phys., 12, 11199-11211, doi:10.5194/acp-12-11199-2012, 2012.

Spyrou, C., Mitsakou, C., Kallos, G., Louka, P., and Vlastou, G.: An improved limited-area model for describing the dust cycle in the atmosphere, J. Geophys. Res., 115, D17211, doi:10.1029/2009JD013682, 2010.

Takemi, T.: Structure and evolution of a severe squall line over the arid region in Northwest China, Mon. Weather Rev., 127, 13011309, 1999.

Takemi, T.: Explicit simulations of convective-scale transport of mineral dust in severe convective weather, J. Meteorol. Soc. Jpn., 83A, 187-203, 2005.

Voss, K. A., Famiglietti, J. S., Lo, M., de Linage, C., Rodell, M., and Swenson, S. C.: Groundwater depletion in the Middle East from GRACE with implications for transboundary water management in the Tigris-Euphrates-Western Iran region, Water Resour. Res., 49, 904-914, doi:10.1002/wrcr.20078, 2013.

Vukovic, A., Vujadinovic, M., Pejanovic, G., Andric, J., Kumjian, M. R., Djurdjevic, V., Dacic, M., Prasad, A. K., El-Askary, H. M., Paris, B. C., Petkovic, S., Nickovic, S., and Sprigg, W. A.: Numerical simulation of "an American haboob", Atmos. Chem. Phys., 14, 3211-3230, doi:10.5194/acp-14-3211-2014, 2014. 
Winker, D. M., Vaughan, M. A., Omar, A., Hu, Y., Powell, K. A., Liu, Z., Hunt, W. H., and Young, S. A.: Overview of the CALIPSO mission and CALIOP data processing algorithms, J. Atmos. Ocean. Tech., 26, 2310-2323, doi:10.1175/2009JTECHA1281.1, 2009.
Zhang, K. M., Knipping, E. M., Wexler, A. S., Bhave, P. V., and Tonnesen, G. S.: Size distribution of sea-salt emissions as a function of relative humidity, Atmos. Environ., 39, 3373-3379, 2005. 